NBER WORKING PAPER SERIES

\title{
CORPORATE TAXATION AND BILATERAL FDI WITH THRESHOLD BARRIERS
}

\author{
Assaf Razin \\ Yona Rubinstein \\ Efraim Sadka \\ Working Paper 11196 \\ http://www.nber.org/papers/w11196
}

\author{
NATIONAL BUREAU OF ECONOMIC RESEARCH \\ 1050 Massachusetts Avenue \\ Cambridge, MA 02138 \\ March 2005
}

Parts of this paper were written while Razin and Sadka were visiting the Economic Policy Research Unit (EPRU) at the University of Copenhagen, in early February 2005. We wish to thank Doina Radulescu and Alon Cohen for competent research assistance. The views expressed herein are those of the author(s) and do not necessarily reflect the views of the National Bureau of Economic Research.

(C) 2005 by Assaf Razin, Yona Rubinstein, and Efraim Sadka. All rights reserved. Short sections of text, not to exceed two paragraphs, may be quoted without explicit permission provided that full credit, including (C) notice, is given to the source. 
Corporate Taxation and Bilateral FDI with Threshold Barriers

Assaf Razin, Yona Rubinstein, and Efraim Sadka

NBER Working Paper No. 11196

March 2005

JEL No. F3, H2, F1

\begin{abstract}
$\underline{\text { ABSTRACT }}$
The paper brings out the special mechanism through which taxes influence bilateral FDI, when investment decisions are two-fold in the presence of fixed setup flows costs. For each pair of sourcehost countries, there is a set of factors determining whether aggregate FDI flows will occur at all, and a different set of factors determimnig the volume of FDI flows (provided that they occur). We demonstrate that the notion that the mere international tax differetials are a key factor behind the direction and magnitude of FDI flows is too simple. We argue that the source country tax rate works primarely on the selection process, whereas the host-country tax rate affect mainly the magnitude of the FDI, once they occur. We analyze international panel data with 24 OECD countries over the period 1981-1998 by the Heckman selection method to bring evidence in support of this argument.

Assaf Razin

Eitan Berglas School of Economics

Tel Aviv University

Tel Aviv 69978

ISRAEL

and NBER

razin@post.tau.ac.il

Yona Rubinstein

Tel Aviv University

yonar@post.tau.ac.il

Efraim Sadka

Tel Aviv University

sadka@post.tau.ac.il
\end{abstract}




\section{Introduction}

"European countries have been steadily slashing corporate-tax rates as they vie for foreign investment, potentially adding to pressure on the U.S. for similar cuts as it weighs a tax overhaul. Following the lead of Ireland, which dropped its rates to $12.5 \%$ from $24 \%$ between 2000 and 2003, one nation after another has moved toward flatter, lower corporate rates with fewer loopholes" (Wall Street Journal Europe, January 28-30, 2005).

Indeed, the economic literature has extensively dealt with the effects of taxation on investment, going back to the well-known works of Harbeger (1962) and Hall and Jorgenson (1967). Of particular interest in this era of increasing globalization are the effects of international differences in tax rates on foreign direct investment (FDI); see, for instance, Auerbach and Hassett (1993), Hines (1999), Desai and Hines (2001), De Mooij and Ederveen (2001), and Devereux and Hubbard (2003).

In this paper we attempt to provide a new look at the mechanisms through which corporate tax rates influence aggregate FDI flows. Specifically, we assume "lumpy" setup costs for new investment. This specification, which has been recently supported empirically by Caballero and Engel (1999, 2000), creates a situation in which FDI decisions are two-fold: whether to export FDI at all, and, if so, how much. These decisions are pair-wise: that is, they are made by each source country with respect to each host country, as the "lumpy" cost is specific for each source-host pair.

In this context, the source and host tax rates may have different effects on these two decisions. This is the subject matter of our empirical investigation, where we apply the Heckman selection method to international panel data of OECD countries.

The organization of this paper is as follows. The next section provides a simple conceptual framework for the analysis of the effects of taxation on 
two-fold FDI decisions. Section 3 presents the data and empirical findings. Section 4 concludes.

\section{Source and Host Taxation}

Elsewhere (Razin, Rubinstein and Sadka (2004)) we emphasize the two-fold nature of investment decisions. In the presence of fixed setup costs of new investment, a firm determines how much to invest according to the standard marginal productivity conditions. For this decision, the setup costs play no role. But in the presence of fixed setup costs, the profits, that are generated when the firm carries out the amount of investment called for by marginal productivity conditions, may be negative. Therefore, the firm faces also a decision whether to incur the setup costs and invest at all. Thus, the investment decision of the firm is two-fold: whether to invest at all, and if so, how much to invest. Indeed, in Razin, Rubinstein and Sadka (2004) we provide evidence in support of this two-fold mechanism of investment in the context of foreign direct investment. Looking at aggregate FDI inflows and outflows among all potential source-host pairs of OECD countries, we find a large proportion of such pairs with no FDI flows at all. Following the two-fold decision mechanism, we accordingly estimate jointly a selection equation (whether to invest all) and a flow equation (how much to invest). The estimation results point out to the importance of fixed setup costs of new investments for the determination of aggregate FDI flows.

Consider for concreteness the case of a parent firm that weighs the development of a new product line. We can think of the fixed setup costs as the costs of developing the product line. The firm may choose to make the development at home and then carry the production at a subsidiary abroad. This choice may be determined by some "genuine" economic considerations such as source-host differences in labor costs, in infrastructure, in human capital, etc. But it may also be influenced by tax considerations. 
In this context of FDI, there arises the issue of double taxation. The income of a foreign affiliate is typically taxed by the host country. If the source country taxes this income too, then the combined (double) tax rate may be very high, and even exceeds $100 \%^{1}$. This double taxation is typically relieved at the source country by either exempting foreign-source income altogether or granting tax credits ${ }^{2}$. In the former case, foreign-source income is subject to the tax levied by the host country only. When the source country taxes its resident on their world-wide income and grants full credit for foreign taxes, then in principle the foreign-source income is taxed at the source-country tax rate, so that the host-country tax rate becomes irrelevant for investment decisions in the source country. But, in practice, foreignsource income is far from being taxed at the source country rate. First, there are various reduced tax rates for foreign-source income. Second, foreignsource income is usually taxed only upon repatriation, thereby effectively reducing the present value of the tax. Thus, in practice, the host country tax-rate is much relevant for investment decisions of the parent firm at the source country. The relevance of the host-country tax rate intensifies through transfer pricing.

To highlight the issue of source-host differences in tax rates, suppose that the source country does not tax foreign-source income at all. Denote the fixed cost of development by $c$. Now, if the host-country tax rate is lower than that of the source country, then the parent firm at the source country attempts to keep this cost at home for tax purposes. The firm may thus charge its subsidiary artificially low royalties for the right to produce the new product. Thus, this cost remains largely deductible in the high-tax source country. Denote the (maximized) present value of the cash flows arising from the production and sale of the new product by $v\left(\tau_{H}\right)$; as explained above, it depends (negatively) on the corporate tax rate $\left(\tau_{H}\right)$ levied by the host

\footnotetext{
${ }^{1}$ For a succinct review of this issue see, for exmaple, Hines(2001).

${ }^{2}$ This is also the recommendation of the OECD model tax treaty (OECD, 1997). A similar recommendation is made also by the United Nations model tax treaty (U.N. 1980).
} 
country. Thus, the parent firm will indulge into the project if

$$
c\left(1-\tau_{S}\right) \leq v\left(\tau_{H}\right)
$$

where $\tau_{S}$ is the corporate tax rate in the source country ${ }^{3}$.

As is evident from condition (1), the tax rate in the source country, $\tau_{S}$, affects positively the decision by a parent firm in country $S$ whether to carry a foreign direct investment in country $H$; whereas the tax rate in the host country, $\tau_{H}$, has a negative effect on this decision.

The amount of foreign direct investment is determined by the standard marginal productivity conditions derived from the maximization of the present value of the cash flows of the foreign subsidiary, after taxes paid in the host country. Therefore, the tax rate in host country $\left(\tau_{H}\right)$ has a negative effect on the flow of FDI from $\mathrm{S}$ to $\mathrm{H}$; whereas the tax rate in the source country $\left(\tau_{S}\right)$ is irrelevant for the determination of the magnitude of their flow.

\section{Empirical Evidence}

Our economic approach is based on Razin, Rubinstein and Sadka (2004), where attention is paid to the problems that arise when FDI flows are "lumpy": FDI flows are actually observed only when their profitability exceeds a certain (unobserved) threshold, as indicated by condition (1). Therefore, the Heckman selection-bias method is adopted to jointly estimate the likelihood of surpassing this threshold (the "selection" equation) and the magnitude of the FDI flow, provided that the threshold is indeed surpassed (the "flow" equation).

\footnotetext{
${ }^{3}$ When the tax-allowed depreciation is close to the true physical (or economic) depreciation, investments are financed primarily by debt, then $v\left(\tau_{H}\right)$ may be approximated by $\left(1-\tau_{H}\right) v_{0}$, where $v_{0}$ is the pre-tax present value of the cash flows of the subsidiary; see, for instance, Auerbach (2002), and Hasset and Hubbard (1996). In this case, condition (1) is approximated by $c\left[1-\left(\tau_{S}-\tau_{H}\right)\right] \leqq v_{0}$, where we note that $\left(1-\tau_{S}\right) /\left(1-\tau_{H}\right)$ is approximated by $1-\left(\tau_{S}-\tau_{H}\right)$.
} 
As was already pointed out in section 2, there are indeed H-S pairs for which no FDI flows appear in the data (covering 18 years). This probably indicates that the FDI flows called for by the standard marginal productivity conditions are not large enough to surpass a certain threshold level as the one described in condition (1), rather than that the desired flows, in the absence of a threshold, are actually zero. The traditional Ordinary Least Squares (OLS) methods treat the no-flow observations as either literally indicating zero flows, and assign a value of zero for the FDI in these observations, or discard these observations altogether. In both cases the estimates are biased.

We employ 3-year averages, so that we have six periods (each consisting of 3 years). The main variables we employ are: (1) standard country characteristics, such as GDP or GDP per-capita, population, educational attainment (as measured by average years of schooling), language, financial risk ratings, etc.; (2) S-H source-host pair, characteristics, such as S-H FDI flows, geographical distance, common language (zero-one variable), S-H flows of goods, bilateral telephone traffic per-capita as a proxy for informational distance, etc.; (3) corporate-tax rates ${ }^{4}$. Table 1 describes the list of the 24 countries in the sample, and whether they are observed in the sample (at least once) as a source or host country (but most source countries do not have positive flows more than with few host countries), and Table 2 describes the data sources.

The data employed in the empirical analysis are drawn from OECD reports (OECD, various years) on a sample of 24 OECD countries, over the period from 1981 to 1998. The FDI data are based on the OECD reports of FDI exports from 17 OECD source countries to 24 OECD host countries ${ }^{5}$.

\footnotetext{
${ }^{4}$ We simply apply the statutory rates, because they are exogenously given. Average effective tax rates, suggested by Deverux and Griffith (2003) as determinants of the location of invetsments, are endogenous in the sense that they are determined by the amount of invetsment. To apply econometrically average effective tax rates, there is a need for a good instrument. The statutory rate is the best available instrument.

${ }^{5}$ The OECD reports accurately on all rich and poor countries that are a host to OECD FDI exports. But data are missing for non-OECD countries as a source of FDI exports. This is the reason that we restrict our sample to the group of OECD countries, as potential source and host countries, among themselves, with no missing data.
} 
Table 3 presents the effects of several potential explanatory variables of the two-hold decisions on FDI flows. Our focus is on the role of the source and host corporate-tax rates.

But we naturally include in the empirical analysis a host of standard explanatory/control variables that are employed in studies of the determination of FDI flows. We briefly discuss these determinants first. They are analyzed in details in Razin, Rubinstein and Sadka (2004). These variables includes standard "mass" variables (the source and the host population sizes); "distance" variables (physical distance between the source and host countries and whether or not the two countries share a common language); and "economic" variables (source and host GDP per capita, source-host differences in average years of schooling, and source and host financial risk ratings). In addition, we include a dummy variable (previous FDI) to indicate whether or not the source-host pair of countries have already established FDI relations between them in the past; such past relations may have some bearing on the setup costs of establishing a new relation. As explained in detail in Razin, Rubinstein and Sadka (2004), the OLS estimates of the effects of these variables are biased. This is true for both the OLS-D regression, where the observations with no FDI flows are discarded (leaving only 851 observations out of the 2116 observations in the full sample); and for the OLS-Zero regressions, where the no-flow observations were recorded as having FDI flows of zero $^{6}$. Note that the difference in the coefficients between OLS-D and OLSZero indicate that there exist non linear relationships between the dependent variable and the independent variables. The Heckman method is suitable for estimating such non linear relationships. The Heckman joint estimation of the flow and selection equations are presented in the last two columns. We exclude certain variables from the flow equation for identification. The results are more or less in line with findings in Razin, Rubinstein and Sadka

\footnotetext{
${ }^{6}$ More accurately, as we measured FDI by logs, we put a large negative number for these FDI flows.
} 
(2004). For instance, a high gap in education in favor of the source country reduces the probability of having FDI flows to the host country. This is expected because a gap in years of schooling may be a proxy for a productivity gap; see also Lucas (1990). The host financial risk rating affects positively the flow of FDI, whereas the analogous variable of the source country is negative and significant in the selection equation. Finally, the existence of past FDI relations is positive and significant in the selection equation, as it may help to reduce the setup costs of establishing a new FDI flow.

We turn now to the main focus of the paper - the effect of corporatetax rates. First, the source corporate-tax rate is positive and significant in the selection equation, as indeed predicted by condition (1) of the preceding section. This rate plays no statistically significant role in the flow equation, again in line with our analysis. The coefficient of the host corporate-tax rate is indeed negative, although insignificant in the selection equation. But it is negative and significant in the flow equation, again as predicted by our analysis. Note that it is not merely the source-host tax differential $\left(\tau_{S}-\tau_{H}\right)$ which is the main determinant of FDI flows.

Interestingly, the role of the source and host corporate-tax rates is not fully revealed by the traditional OLS regressions. In the regression (OLSD), only the host corporate-tax rate plays a statistically significant role in reducing FDI flows to the host country; whereas in the other regression (OLSZero), it is only the source corporate-tax rate which plays a statistically significant role in promoting FDI outflows from the source country ${ }^{7}$. Thus, OLS analysis does not detect a role for both tax rates to play in the determination of FDI.

Note that the relationship in the selection equation between the probability $(P)$ of making a new FDI and the explanatory variables (including $\tau_{S}$ )

\footnotetext{
${ }^{7}$ We performed also several robustness tests. For instance, we excluded the host and source financial risk ratings from the flow equation. We also deleted the variable "previous FDI" from both equations. The results concerning the corporate-tax rates seem quite robust.
} 
is not linear. It is rather given by

$$
P\left(\tau_{S}\right)=\int_{-\infty}^{\alpha+\beta \tau_{S}}(2 \pi)^{-1 / 2} \exp \left(-y^{2} / 2\right) d y
$$

where $\alpha$ represents the effect of all the other explanatory variables (held fixed at their sample averages), including country fixed effects, and $\beta$ is the coefficient of $\tau_{S}$ in the selection equation. Note also that the estimate of $\beta$ is positive and statistically significant. The marginal effect of $\tau_{S}$ on $P$ is

$$
\partial P / \partial \tau_{S}=\beta(2 \pi)^{-1 / 2} \exp \left[-\left(\alpha+\beta \tau_{S}\right)^{2} / 2\right]>0 .^{8}
$$

Figure 1 depicts the graph of the function $P\left(\tau_{S}\right)$ for the U.S. as a source country and four EU countries (Denmark, Greece, the Netherlands and the U.K.) as host countries. The U.S.-U.K. characteristics in the sample are such that the estimated probability of a positive FDI flow from the U.S. to the U.K. is one, unaffected by the source country (namely, U.S.) tax rate. For all other three countries, the U.S. tax rate has a strong positive effect in the relevant range of $0-40 \%$. But the marginal effects of the source-country tax rate is not the same for all three countries, being highest for Greece. Figure 2 depicts the flow equation for the U.S., as a source country, and the four EU countries as host countries. The host-country tax rate seems to have a negative effect at all rates, including the very high rates that approach $100 \%$. Notably, the tax rate of the U.K. (as a host country) has a very strong negative marginal effect, whereas in the tax rate of Greece has a relatively small marginal effect.

\footnotetext{
${ }^{8}$ To complete the picture, note also that $P\left(\tau_{S}\right)$ has an inflection point at $\tau_{S}=-\alpha / \beta$.
} 


\section{Conclusion}

We analyze the effects of taxes on bilateral FDI flows. Evidently, economists and pacemakers reckon with the fact that taxes do affect economic international flows of goods and capital. Bilateral FDI flows are no exception. Our aim is to bring out the special mechanisms through which taxes influence FDI, when investment decisions are likely to be two-fold because of the existence of fixed setup costs of new investments. Specifically, for each pair of source-host countries, there is a set of factors determining whether aggregate FDI flows will occur, and a different set of factors determining the volume of FDI flows, given that they at all occur. We demonstrate that the notion that the mere international tax differentials are the main factors behind the direction and magnitude of FDI flows is too simple. We hypothesize that the source-country tax rate works primarily on the selection process, whereas the host-country tax rate affects mainly the magnitude of the FDI, once they occur ${ }^{9}$. Analyzing an international panel data of 24 OECD countries, we bring empirical evidence, using selection bias methods, in support of this hypothesis.

\footnotetext{
${ }^{9}$ This finding has some bearing on the nature of international tax competition, as is evident from the citation at the beginning of the paper; for an overview of the traditional analysis of international taxation see, for instance, Frenkel, Razin and Sadka (1991), Wilson (1999), and Haufler (2001).
} 


\section{References}

[1] Auerbach, Alan J. (2002), "Taxation and Corporate Financial Policy", in Alan J. Auerbach and Martin Feldstein (eds.), Handbook of Public Economics, Vol. 3, 1251-92, North-Holland, Amsterdam.

[2] Auerbach, Alan J. and Kevin Hassett (1993), "Taxation and Foreign direct Investment in the United States: A Reconsideration of the Evidence", in: Alberto Giovannini, R. Glenn Hubbard, and Joel Slemrod (eds.) Studies in International Taxation, University of Chicago Press, 119-144.

[3] Caballero, Ricardo and Eduardo Engel (1999), "Explaining Investment Dynamics in US Manufacturing: A Generalized (S;s) Approach", Econometrica, July, 741-82.

$[4]$ (2000), "Lumpy Adjustmet and Aggregate Investment Equations: A "Simple" Approach Relying on Cash Flow "Information", mimeo.

[5] De Mooij, R.A., and S. Ederveen (2001), "Taxation and Foreign Direct Investment: A Synthesis of Empirical Research", CESifo Working Paper No. 588 .

[6] Desai, Mihir A. and James R. Hines (2001), "Foreign Direct Invetsment in a World of Multiple Taxes", University of Michigan.

[7] Devereux, Michael P. and Rachel Griffith (2003), "Evaluating Tax Policy for Location Decisions", International Tax and Public Finance, 10(2), 107-126.

[8] Devereux, Michael P. and R. Glenn Hubbard (2003), "Taxing Multinational", International Tax and Public Finance, 10(4), 469-488. 
[9] Frenkel, Jacob A., Assaf Razin and Efraim Sadka (1991), International Taxation in an Integrated World Economy, MIT press.

[10] Hall, Robert E. and Dale W. Jorgenson (1967), "Pax Policy and Investment Behavior", American Economic Review, 57, 391-414.

[11] Harberger, Arnold C. (1962), "The Incidence of The Corporation Income Tax", Journal of Political Economy, 70, 215-40.

[12] Hassett, Kevin A. and R. Glenn Hubbard (1996), "Tax Policy and Investment", NBER Working Paper No. 5683.

[13] Haufler, Andreas (2001), Taxation in a Global Economy, Cambridge University Press.

[14] Hines, James R. (1999), "Lessons from Behavioral Responses to International Taxation", National Tax Journal, 53, 305-22.

[15] Hines, James R. (2001), "Corporate Taxation", in Neil J. Smelser and Paul B. Balts (eds.), International Encyclopedian of the Social and Behavioral Sciences.

[16] Lucas, Robert E. (1990), "Why Doesn't Capital Flow from Rich to Poor Countries?", American Economic Review: Papers and Proceedings, 80(2), 92-96.

[17] OECD (1997), Model Tax Convention on Income and on Capital, Pairs, OECD Committee on fiscal Affairs.

[18] Razin, Assaf, Yona Rubinstein and Efraim Sadka (2004), "Fixed Costs and FDI: The Conflicting Effects of Productivity Shocks", NBER Working Paper No. 10864.

[19] U.N. (1980), "U.N. Model Double Taxation Convention between Developed and Developing Countries", U.N. Document \# ST/ESA/102. 
[20] Wilson, John D. (1999), "Theories of Tax Competition", National Tax Journal, 52, 269-304. 
Table 1: Frequency of Source-Host Positive Flows by Countries

\begin{tabular}{|l|l|l|l|l|l|}
\hline Country & Source & Host & Country & Source & Host \\
\hline \hline Australia & 0.43 & 0.41 & Korea & 0.09 & 0.39 \\
Austria & 0.66 & 0.38 & Mexico & 0.00 & 0.33 \\
Belgium & 0.03 & 0.56 & Netherlands & 0.68 & 0.54 \\
Canada & 0.62 & 0.41 & New Zealand & 0.00 & 0.34 \\
Denmark & 0.35 & 0.46 & Norway & 0.64 & 0.33 \\
Finland & 0.65 & 0.34 & Portugal & 0.00 & 0.49 \\
France & 0.94 & 0.52 & Spain & 0.02 & 0.51 \\
Germany & 0.98 & 0.54 & Sweden & 0.84 & 0.45 \\
Greece & 0.00 & 0.36 & Switzerland & 0.27 & 0.47 \\
Ireland & 0.00 & 0.49 & Turkey & 0.02 & 0.36 \\
Italy & 0.81 & 0.46 & United Kingdom & 0.91 & 0.58 \\
Japan & 0.96 & 0.41 & United States & 0.87 & 0.64 \\
\hline
\end{tabular}




\section{Table 2: Data Sources}

\begin{tabular}{ll} 
Variables: & Source: \\
\hline \hline Import of Goods & Direction of Trade Statistics, IMF \\
FDI Inflows & International Direct Investment Database, OECD \\
Unit Value of Manufactured Exports & World Economic Outlook, IMF \\
Population & International Financial Statistics, IMF \\
Distance & Shang Jin Wel's Website: www.nber.org/ ${ }^{\sim}$ wei \\
Bilateral Telephone Traffic & Direction of Traffic: \\
& Trends in International Telephone Tariffs, \\
& International Communication Union \\
& International Telecommunication Union \\
Educational Attainment & Barro-Lee Dataset: www.nber.org/N.... \\
ICRG Index of Financially Sound & Ashoka Mody, IMF \\
Ratings (inverse of financial risk) & \\
Corporate Tax Rates & World Tax Database (University of Michigan) \\
& http://www.bus.umich.edu/otpr/worldtaxdatabase.htm
\end{tabular}


Table 3: The Effects of Host and Source Corporate-Tax Rates on FDI

\begin{tabular}{|c|c|c|c|c|}
\hline & \multirow[b]{2}{*}{ OLS-D } & \multirow[b]{2}{*}{ OLS-Zero } & \multicolumn{2}{|c|}{ Heckman Estimation } \\
\hline & & & Flow & Selection \\
\hline Source Tax Rate ${ }^{1}$ & $\begin{array}{l}1.880 \\
(1.175)\end{array}$ & $\begin{array}{l}2.420^{* *} \\
(0.717)^{* *}\end{array}$ & $\begin{array}{l}1.168 \\
(1.236)\end{array}$ & $\begin{array}{l}\mathbf{5 . 6 1 4} 4^{* *} \\
(1.821)^{* *}\end{array}$ \\
\hline Host Tax Rate ${ }^{1}$ & ${ }^{-3.461^{* *}}$ & $\begin{array}{c}-0.683 \\
(0.763)\end{array}$ & $\begin{array}{c}-3.636^{* *} \\
(1.103)^{* *}\end{array}$ & $\begin{array}{l}2.568 \\
(1.538)\end{array}$ \\
\hline Host Real GDP per Capita ${ }^{2}$ & $\begin{array}{l}0.088 \\
(0.704)\end{array}$ & $\begin{array}{l}0.198 \\
(0.463)\end{array}$ & $\begin{array}{c}-0.046 \\
(0.723)\end{array}$ & $\begin{array}{l}0.280 \\
(0.889)\end{array}$ \\
\hline Source Real GDP per Capita ${ }^{2}$ & $\begin{array}{l}0.258 \\
(0.757)\end{array}$ & $\begin{array}{l}0.311 \\
(0.318)\end{array}$ & $\begin{array}{l}0.095 \\
(0.774)\end{array}$ & $\frac{-4.697^{*}}{(2.390)^{*}}$ \\
\hline Host Population $^{2}$ & $\frac{-4.810^{*}}{(2.332)^{*}}$ & $\begin{array}{l}0.592 \\
(1.641)\end{array}$ & ${ }^{-6.524^{* *}}{ }^{* 2.350)^{* *}}$ & ${ }_{(2.906)^{* *}}^{10.147^{* *}}$ \\
\hline Source Population $^{2}$ & $\begin{array}{l}0.330 \\
(2.843)\end{array}$ & $\begin{array}{l}0.973 \\
(1.508)\end{array}$ & $\begin{array}{c}-0.739 \\
(2.748)\end{array}$ & $\begin{array}{c}-2.000 \\
(3.732)\end{array}$ \\
\hline Source-Host Difference in Schooling ${ }^{3}$ & $\begin{array}{c}-0.009 \\
(0.093)\end{array}$ & $\begin{array}{c}-0.066 \\
(0.056)\end{array}$ & $\begin{array}{l}0.034 \\
(0.102)\end{array}$ & $\begin{array}{c}-0.287^{* *} \\
(0.107)^{* *}\end{array}$ \\
\hline Common Language $^{4}$ & $\begin{array}{c}0.922 \\
(0.136)^{* *}\end{array}$ & $\begin{array}{c}0.453^{* *} \\
(0.119)^{* *}\end{array}$ & $\underset{(0.123)^{* *}}{0.892^{* *}}$ & $\begin{array}{c}\mathbf{0 . 3 9 2}^{* *} \\
(0.189)^{* *}\end{array}$ \\
\hline Source-Host Distance ${ }^{5}$ & $\begin{array}{c}-0.689^{* *} \\
(0.087)^{* *}\end{array}$ & ${ }_{(0.069)^{* *}}^{-0.389^{* *}}$ & ${ }_{(0.082)^{* *}}^{-0.663^{* *}}$ & $\begin{array}{c}-0.415^{* *} \\
(0.099)^{* *}\end{array}$ \\
\hline Host Financial Risk Rating 6 & $\begin{array}{l}0.049^{* *} \\
(0.017)^{* *}\end{array}$ & $\begin{array}{c}-0.005 \\
(0.012)\end{array}$ & $\underset{(0.017)^{* *}}{0.060^{* *}}$ & $\begin{array}{c}-0.023 \\
(0.026)\end{array}$ \\
\hline Source Financial Risk Rating ${ }^{6}$ & $\frac{-0.082^{* *}}{(0.030)^{* *}}$ & $\begin{array}{c}-0.036^{* *} \\
(0.011)^{* *}\end{array}$ & & $\begin{array}{c}-0.138^{* *} \\
(0.050)^{* *}\end{array}$ \\
\hline Previous $\mathrm{FDI}^{7}$ & $\begin{array}{l}0.3955^{* *} \\
(0.129)^{* *}\end{array}$ & $\begin{array}{l}1.526 \\
(0.200)^{* *}\end{array}$ & & $\begin{array}{l}0.630^{* *} \\
(0.148)^{* *}\end{array}$ \\
\hline Number of Observations & 851 & 2116 & 2116 & 2116 \\
\hline
\end{tabular}




\section{Notes:}

(a) All estimations include country and time fixed effects

(b) Robust standard errors appear in parentheses

* Indicates significance at the five percent level;

** Indicates significance at the one percent level;

1 In fractions

2 In logs, lagged one period

3 In average years of schooling, lagged one period

4 One for common language; zero otherwise

$5 \quad$ In $\operatorname{logs}$

6 Lagged one period

7 One for existence of previous FDI; zero otherwise 


\section{Figure 1: A Selection Equation (from the U.S. to four EU Countries)}

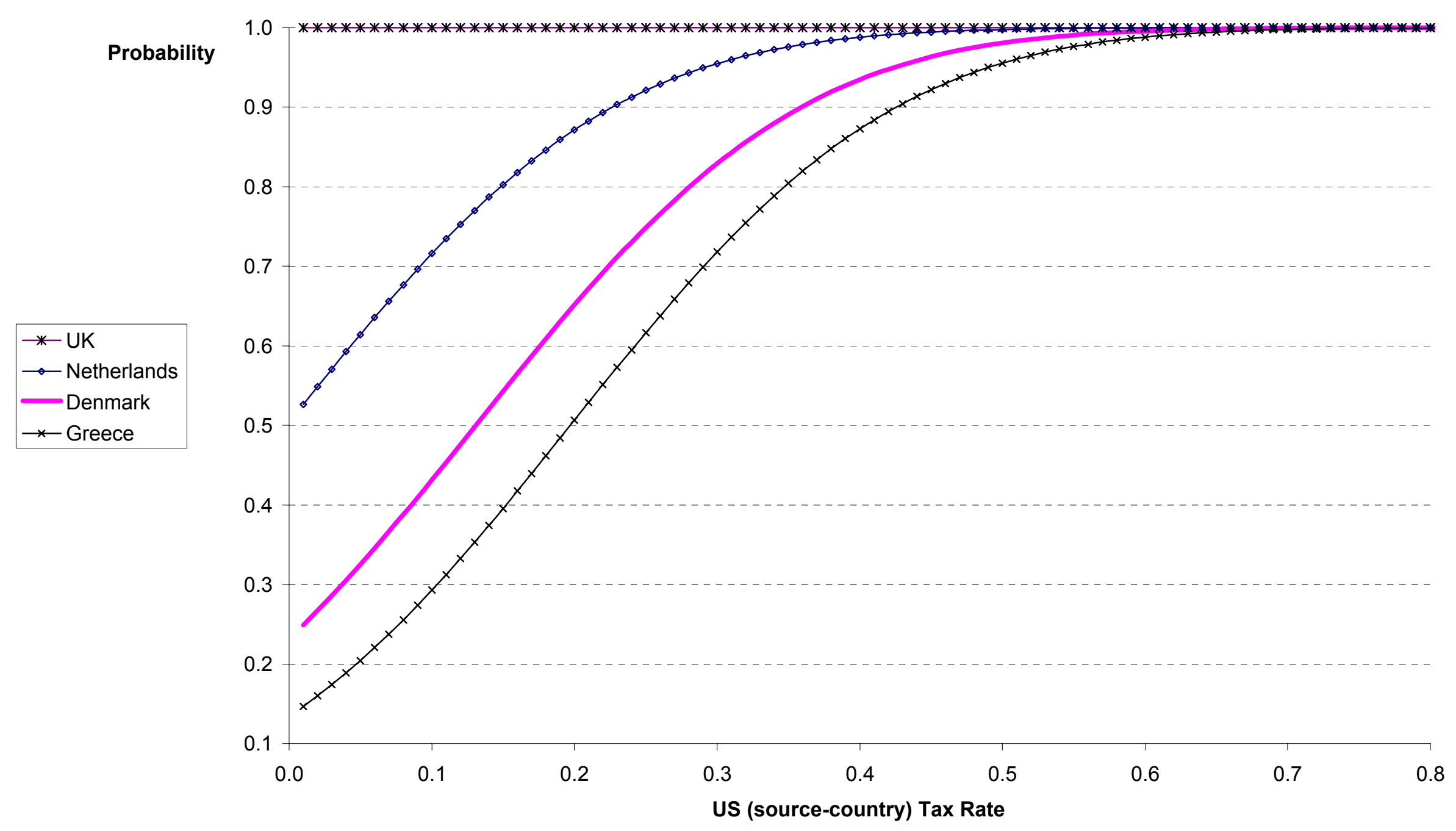




\section{Figure 2: A Flow Equation (from the U.S. to four EU Countries)}

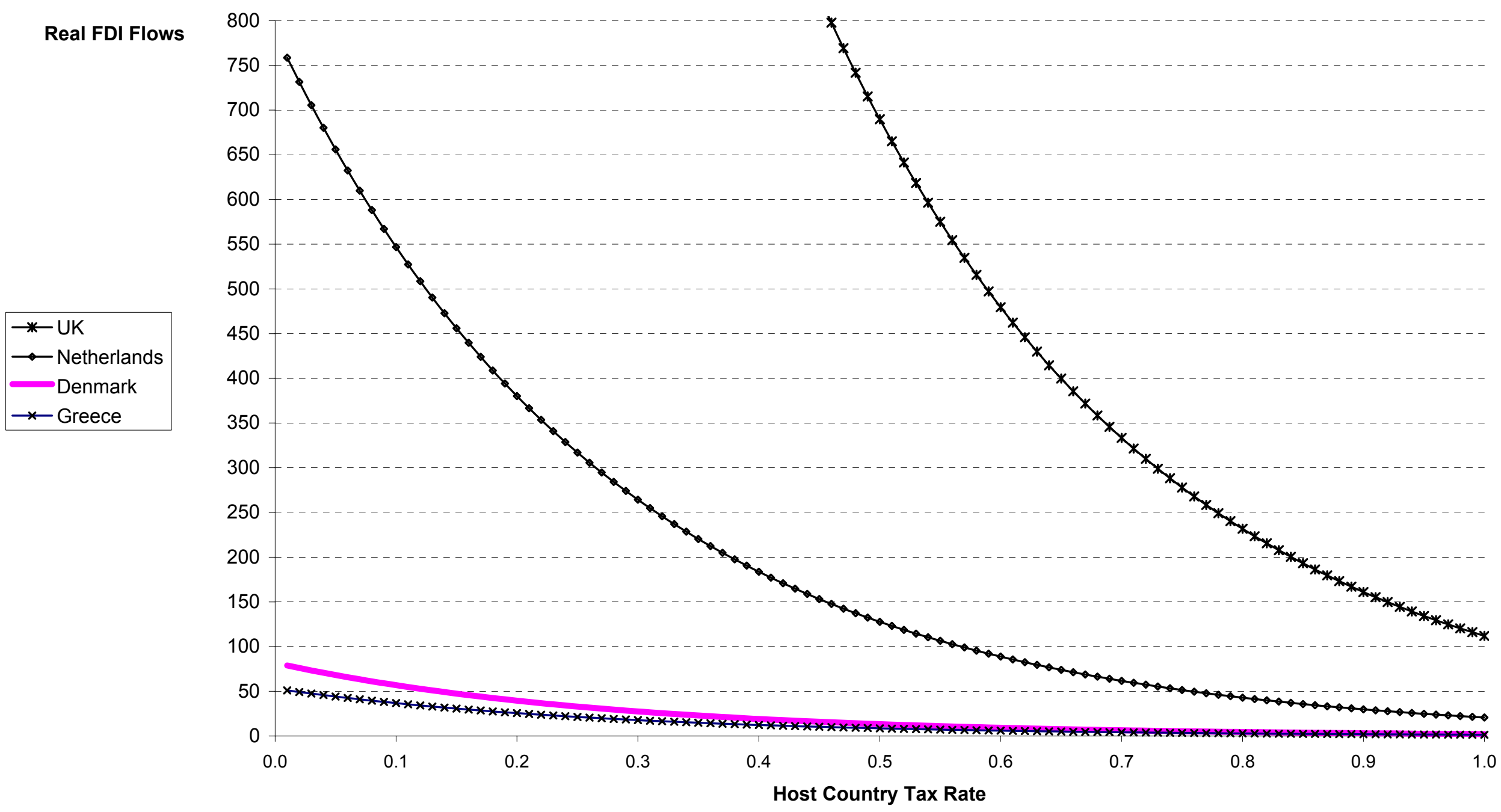

